\title{
Exterior of Multi-Family Residential Buildings and Complexes of a Siberian City on the Example of Krasnoyarsk
}

\author{
Olga Bliankinshtein ${ }^{1, *}$ Olesya Kiselyova ${ }^{1, a}$ Olga Uspenskaya ${ }^{1, b}$ Anastasia \\ Orlova $^{1, \mathrm{c}}$ Anastasia Shlokina ${ }^{1, \mathrm{~d}}$ \\ ${ }^{1}$ School of Architecture and Design, Siberian Federal University, Krasnoyarsk, Russia \\ ${ }^{a}$ E-mail: OKiseleva@sfu-kras.ru \\ ${ }^{b}$ E-mail: OUspenskaya@sfu-kras.ru \\ ${ }^{c}$ E-mail: AAOrlova@sfu-kras.ru \\ ${ }^{d}$ E-mail: AShlokina@sfu-kras.ru \\ *Corresponding author.E-mail: OBlyankinshteyn@sfu-kras.ru
}

\begin{abstract}
The article examines the architectural design of multi-family residential buildings and complexes in Krasnoyarsk, which plays an important role in creating a comfortable city environment. A comprehensive analysis of the exterior of apartment buildings has been carried out in this work. The analysis is based on the study of historical and architectural materials, observation and field examination, photographic recording and comparison. Three periods have been identified: pre-industrial (first half of the 20th century), industrial (second half of the 20th century), post-industrial (early 21st century). The formation of the architectural and artistic appearance of apartment buildings of each period is characterized by fundamental differences. A systematic analysis of nine modern residential multi-apartment complexes was carried out in accordance with the selected parameters. Theoretical generalization and practical work carried out within this research will contribute to further improving the architectural design of multi-family residential buildings and complexes.
\end{abstract}

Keywords: Multi-family residential building, Architectural design, Krasnoyarsk.

\section{INTRODUCTION}

The research is focused on multi-family residential buildings and complexes.

The subject of the research is architectural and art characteristics of multi-family residential buildings and complexes; no detailed consideration of functional planning and design solutions is provided; these issues are considered as part of the context.

Research limitations: territorial and geographical - the city of Krasnoyarsk; typological

*Fund: This article reflects the research carried out within the framework of the project "Comprehensive analysis of functional planning and architectural and art organization of multi-family residential buildings and complexes in Krasnoyarsk", supported by the Krasnoyarsk Regional Science Foundation.
- residential buildings and complexes; period of time - from the beginning of the 20th century up to nowadays.

Research methods: study, observation, photography, collecting statistical materials, field examination of multi-family residential buildings and complexes in Krasnoyarsk, analysis by certain set of parameters, analytical tables, comparison, generalization.

Previous studies on the topic: Serious Russian scientific research on dwelling architecture dates back to 1970-1990. Most of the research studies of recent decades refer to the history, typology, sociology of apartment buildings [1], [2], [3], [4]. Works of several authors are devoted to multiapartment housing in Siberian cities [5], [6]. Nevertheless, the formation of the architectural 
appearance of multi-apartment residential buildings is considered only fragmentarily [7], although they require a detailed study.

We start with philosophic overview of the terms "Heritage", "Traditions", and "Innovations" in architecture. Usually, the chain of these concepts is presented in such an order: Heritage $\rightarrow$ Traditions $\rightarrow$ Innovations. However, this sequence can be observed in the opposite direction as well. An architectural object, if it does not follow the existing pattern/typical project, is always new at the beginning in relation to the already existing objects. Further, it is being improved. Then, if the new pattern is repeated, it becomes traditional, and over time it can become a heritage/a value. Then there may appear something new again, and the sequence of actions is repeated. In this case, the chain of concepts forms the following order "New $\rightarrow$ Traditional $\rightarrow$ Retained/Inherited". To become a "Heritage", an architectural object should be in good condition, be of historical, cultural, architectural and art value, and outlive a certain period of time, possible state, political and social changes. There are multi-family residential buildings in Krasnoyarsk having the status of architectural monuments. This study begins with the examination of these buildings and adheres chronological order.

\section{ARCHITECTURAL AND ART HERITAGE SHAPING MULTI- FAMILY RESIDENTIAL BUILDINGS IN KRASNOYARSK IN THE FIRST HALF OF THE 20TH CENTURY}

Until the beginning of the 20th century, residential buildings in Krasnoyarsk were individual houses and estates, at first in wooden design only, then gradually there appeared more and more houses built of stone. Multi-family residential buildings in Krasnoyarsk appeared in the 19th - early 20th centuries. Small wooden residential buildings for 2-5 families were known in Krasnoyarsk earlier. Construction of stone residential buildings started in the beginning of the 20th century.

Vivid examples of stone residential buildings built in 1910-1914s are: Libman's tenement house (96 Mira Prospect), by the architect V.A. Sokolovsky (Figure 1a); tenement house belonging to the Spiritual Brotherhood at 98 Mira Prospect, by the architect L.A. Chernyshev ("Figure 1"b); the residential building with the Main Post Office (P.I. Degtyarev's residential building, 62 Lenina Street), by the architect V.A. Sokolovsky ("Figure 1"c) [8], [9]. All the three houses are architectural monuments of Krasnoyarsk, built in the provincial Art Nouveau style. They have the same characteristic features of the main facade: plaster finishing and two-color painting; several axes of the front composition; mirror symmetry of the central axis; clear rhythm of vertical lines; the use of risalits, balconies, and bay windows; playing with the sizes and outlines of window openings in the form of an oval, circle, semicircle; curved window muntins; forged metal parts with the characteristic "Whiplash" pattern; stucco floral ornaments, cartouches, masks, hanging paddles. Both buildings in Mira Prospekt have a smooth undulating rise in the eaves of the central part of the facades. The building in Lenina Street has threedimensional decorative endings at the top above the risalits. The top contour of all the three buildings is an amazing combination of eaves and parapets, rich in detail. Only the street facades of these houses are compositionally verified, expressive and decorated. For more than a hundred years they have been creating an elegant ceremonial style of the main streets of the historical city center. Despite the common style, each house has individual characteristics and design. 

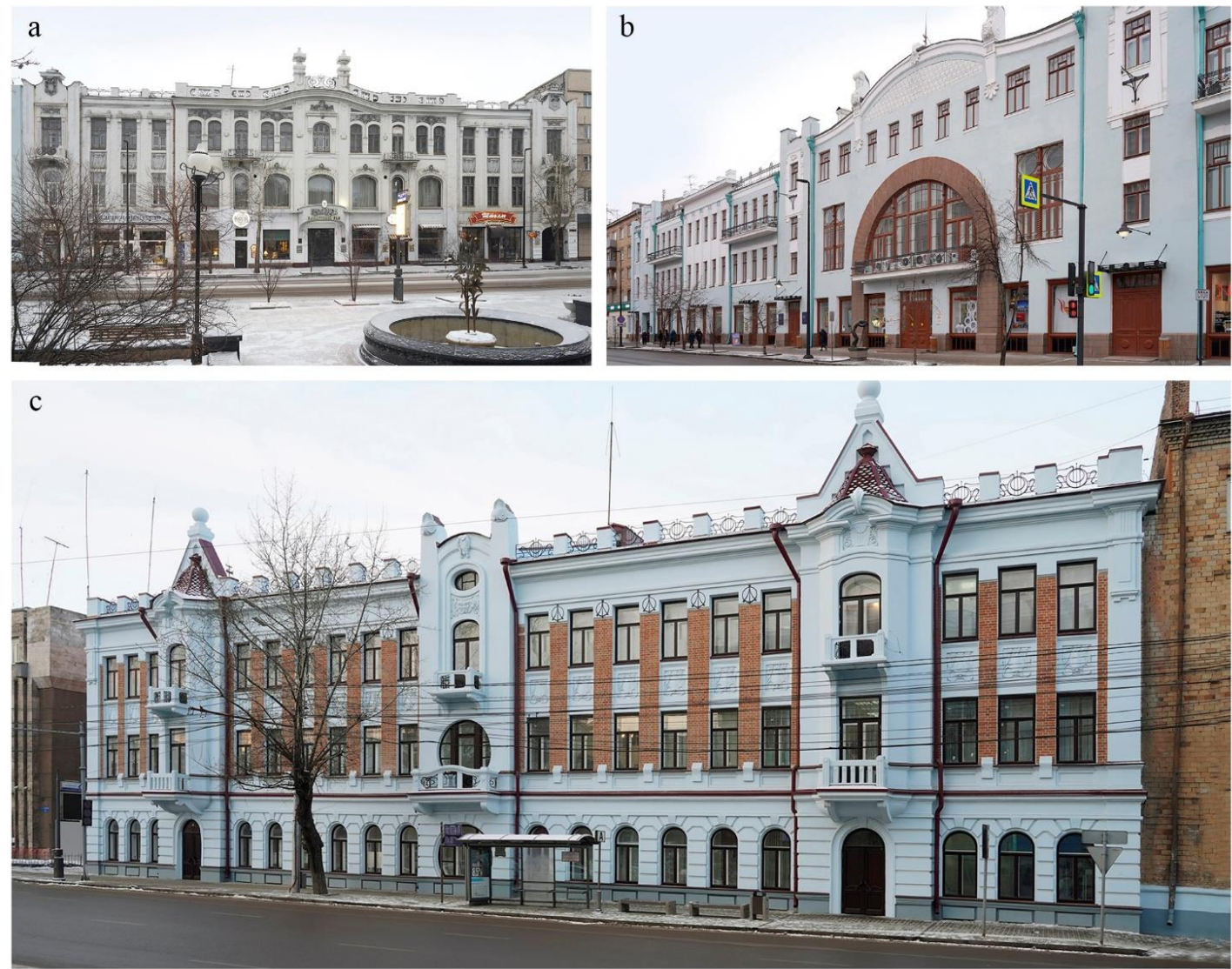

Figure 1 Tenement houses of Krasnoyarsk at the beginning of the 20th century: a - Libman's tenement house (96 Mira Prospect); b - Tenement house of Spiritual Brotherhood (98 Mira Prospect); c - P.I. Degtyarev's residential building (62 Lenina Street).

The next important period in the design and construction of residential buildings is the beginning of the industrialization of the Soviet country in the late 1920s and 1930s. Krasnoyarsk became one of the main cities in Siberia, where new plants and factories were built. Housing construction during this period reached an unusually wide scale. Two-storied, three-storied and even five-storied multi-family residential buildings were built in both wood and stone. Usually, they had strict design without decorative elements.

During this period, the administration of Krasnoyarsk proposed implementing a plan for communal housing construction, which provided multi-family "communal houses": block buildings with public dining rooms, libraries, reading rooms, and nurseries on the ground floors. The architects followed classical style in composition, proportions, scale, spatial proportions and axes formation. a Source: photo by A.V. Patramansky [9].

In Krasnoyarsk the construction of the first residential block called "Kamenny Kvartal" was carried out in the historical part of the city on the territory between the Mira Prospect and Karla Marxa Street, Dekabristov Street and Robespiera Street. The project was developed by the architect S.G. Drizhenko [8]. First of all, he suggested the idea of residential buildings offering public services. The first buildings of the "Kamenny Kvartal" appeared in 1920s. They follow the Constructivist style. These are residential buildings at 105 Mira Prospect ("Figure 2"a), and 20 Robespiera Street ("Figure 2"b). The buildings of the 1930s demonstrate the trends of Neoclassicism, e.g. the residential building at 107 Mira Prospect, ("Figure 2"c). Even more classicist features appear in the building in Karla Marxa, 132. It was built in 1953 for the workers of the radio plant. This block of apartments finalized the "Kamenny Kvartal" and became one of the most recognizable buildings 
because of the corner tower, decorated with an order system and a high spire ("Figure 2"d).
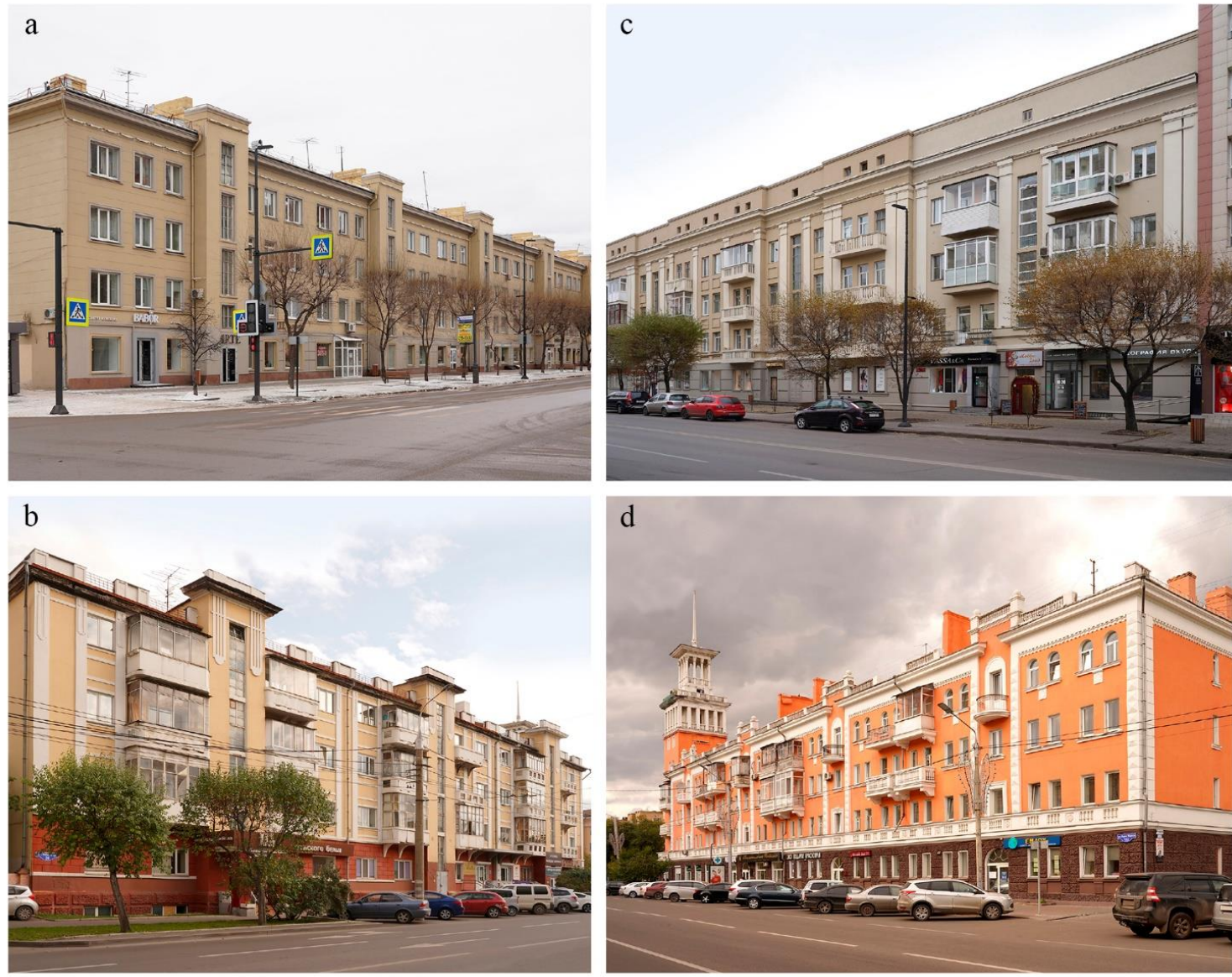

Figure 2 Residential buildings of Krasnoyarsk 1920-1950: a - Residential building (105 Mira Prospect); b Residential building (20 Robespiera Street); c - Residential building (107 Mira Street); d - Residential building (132 Karla Marxa street).

In the historical center of Krasnoyarsk there are monumental buildings in which public institutions are connected to apartment buildings. This is the so-called Soviet or Stalinist Neoclassicism, where order compositions triumph over the rusticated lower tier.

All the residential buildings under consideration represent the architectural and historical heritage of Krasnoyarsk. They are the architectural monuments having characteristic memorable image and still form the architectural design of the historical center of Krasnoyarsk. But being that individual, they could not be multiple, and, accordingly, they could not solve the housing problem of a large industrial city.
Source: photo by A.V. Patramansky[9].

\section{ARCHITECTURAL TRADITIONS SHAPING MULTI-APARTMENT RESIDENTIAL BUILDINGS IN KRASNOYARSK IN THE SECOND HALF OF THE 2OTH CENTURY}

Large-scale provision of the city residents with individual comfortable apartments became possible with the introduction of industrial housing construction when the well-known resolutions of 1955-1957 were adopted ("On elimination of excesses in design and construction", "On housing construction development in the USSR") [10], [11]. The idea of constructing affordable mass housing from large-size pre-made elements was based on the ideas of rationalism and functionalism of Western European countries. This idea received its own interpretation in provincial Soviet architecture. 
First, the so-called "Khrushchevkas" became widespread in Krasnoyarsk. These were standard five-storey houses with long-awaited apartments for one family each. At the end of the 1960s the design was improved, and there appeared "Brezhnevkas". They were 5-storey, 9-storey and 12-storey ones. In Krasnoyarsk, there were constructed numerous "Khrushchevkas" and "Brezhnevkas" on the left and right banks of the Yenisei. Construction of this modest housing reduced the costs significantly, but the architectural design of the housing was completely lost. A detached house was a rectangular parallelepiped with symmetric windows located along the facades. The number of windows corresponded to the number of rooms and kitchens. There was one balcony per apartment. Balconies on the facades were usually grouped vertically one above the other. The length of the house was determined by the number of front doors ensuring vertical communication by means of the internal staircases connecting the floors and providing entrances to the apartments. The front door - the entrance to the staircase could have a simple porch or a canopy, but it might not have them as well. The vertical axis of each entrance was marked not only by the front door, but also by the windows that illuminated the stairs. Five-storey houses usually had a gently sloping roof and, in the case of brick walls, were sometimes decorated with a band under the eaves. By now, the "Khrushchevkas" have long been morally and physically obsolete, their construction has long been stopped, but the existing ones are still used for living. The exterior of these houses nowadays is poor, but able to cause nostalgia in the older generation. "Khrushchevkas" have one advantage over subsequent standard series of apartment buildings - they are of mid-rise, and of human scale.

The search for new shape-forming construction tools in housing was undertaken in the early 1970s. Instead of small-sized five-storey buildings, Krasnoyarsk construction enterprises switched to a new large-panel multi-family residential buildings (Series 97), developed at Novosibirsk Siberian Scientific, Research and Design Institute. The first 9-storey residential buildings of this project design were built in Krasnoyarsk in 1974. Panel houses had well-known advantages and disadvantages. Around the same time, Krasnoyarskgrazhdanproekt Institute developed a series of standard design projects of multi-storey buildings (KZh), the socalled "Improved Design". These panel houses had 9 , or less often 12 or 14 floors, they proved to be very reliable and high quality housing.
The qualitative characteristics of the affordable mass industrial housing gradually increased, but all the experiments on typical design concerned exclusively the layouts of sections and apartments (variety of layouts, eliminating passage rooms, a separate bathroom, spacious corridors), increasing the living and total area of an apartment, increasing the height, and house equipping (elevators, garbage chutes).

The issues of improving the external architectural design of these typical houses were not considered or given little attention to. The socalled "Khrushchevkas", "Brezhnevkas", "Leningradkas", "Improved Design (KZh) Series" and the Series 97 houses are, from the point of view of architecture, primitive boxes of 5/9/12/14 storeys. Most often, residential buildings of this period consisted of several sections (entrances), and the length of the house was determined by the number of sections. The swivel sections projects made it possible to diversify the planning con Figureuration of a residential building. The architectural design of these buildings is simple and ascetic. Dull flat surfaces of exterior walls of gray concrete or brick, with a large number of identical windows, with the same open balconies is the main characteristic feature of these houses. Almost every family tried to make the balcony and loggia glazed. Since this was done in different ways, using different, designed for other purposes materials, the loggias and balconies looked different, which created a feeling of chaos in the exterior design. The seams between the panels, always clearly visible on the walls of panel houses, not always were accurate. The panels of the first large-panel buildings did not have any finishing; subsequently, house-building enterprises began to produce panels with the simplest textures and color finish, which very often dilapidated soon. The division of the facade into panel sets violates the human-based scale, and the absence of any details aggravates visual perception.

Subsequently, in the early 2000s, Series 97 project received significant modernization: the planning became more diverse, the number of storeys increased, and the quality of external wall panels was improved. As a result, the buildings received new, individual facades. Considerable attention was given to the color design of the facades. Details, decorations, and color elements appeared on the external walls. A unified approach to glazing balconies and loggias at the level of design solutions played a significant role in 
harmonizing the overall architectural design of multi-apartment panel residential buildings.

Unfortunately, large-panel residential buildings built in the 1970s-1990s are still used for living in Krasnoyarsk. They do not only form a large number of subdistricts of Krasnoyarsk of the Soviet period, but also coexist with the unique examples of old architecture in the historical part of the city. Now the city faces the paradoxal problem: how to incorporate architectural monuments in the typical "gray" background landscape.

Thus, during the period of the planned economy, Krasnoyarsk, as most Russian cities, was dominated by industrial housing construction. Standard projects were developed in large central research and design institutes, while regional architects introduced minor revisions. Individual design of multi-family residential buildings was practically forgotten, which contributed to the faceless architectural environment.

\section{INNOVATIONS SHAPING ARCHITECTURAL FORMATION OF MULTI-FAMILY RESIDENTIAL COMPLEXES IN KRASNOYARSK AT THE BEGINNING OF THE 21ST CENTURY}

Socio-economic changes in the early 1990s, which led to changes in the housing development of cities throughout the post-socialist system [12], occurred in Russian cities as well. Emerging private customers of housing made it possible to demonstrate individual approach to the residential building. Local design institutes and private design organizations started their work in this area.

A striking example of an individual project implemented in 1999 in Krasnoyarsk is the residential building at 19 Markovskogo Street ("Figure 3"a). There was a difficult task to design a house next to the architectural monument of Krasnoyarsk - the house of the architect L.A. Chernyshev, built in 1911-1913 in the Art Nouveau style ("Figure 3"b). The design office of the architect Balzer coped with the task of the historical neighborhood. A four-storey brick residential building, adjacent to the historic architectural monument, does not spoil the view, it becomes part of it. When designing a modern apartment building, the authors proposed to follow the style of the architectural monument: the new house has the same number of storeys as the old one nearby, brick walls are plastered, the rhythm of bay windows emphasizes the dominant importance of the bay windows of the historical building, its modernist forms and façade details imitate the Art Nouveau style of the architectural monument. This residential building can obviously be called an example of a harmonious individual architectural design, subordinate to the historical architecture in the Art Nouveau style. Such a house is the only one in Krasnoyarsk, it stands apart from the modern mass housing of the city, that is why it is worth a separate consideration.
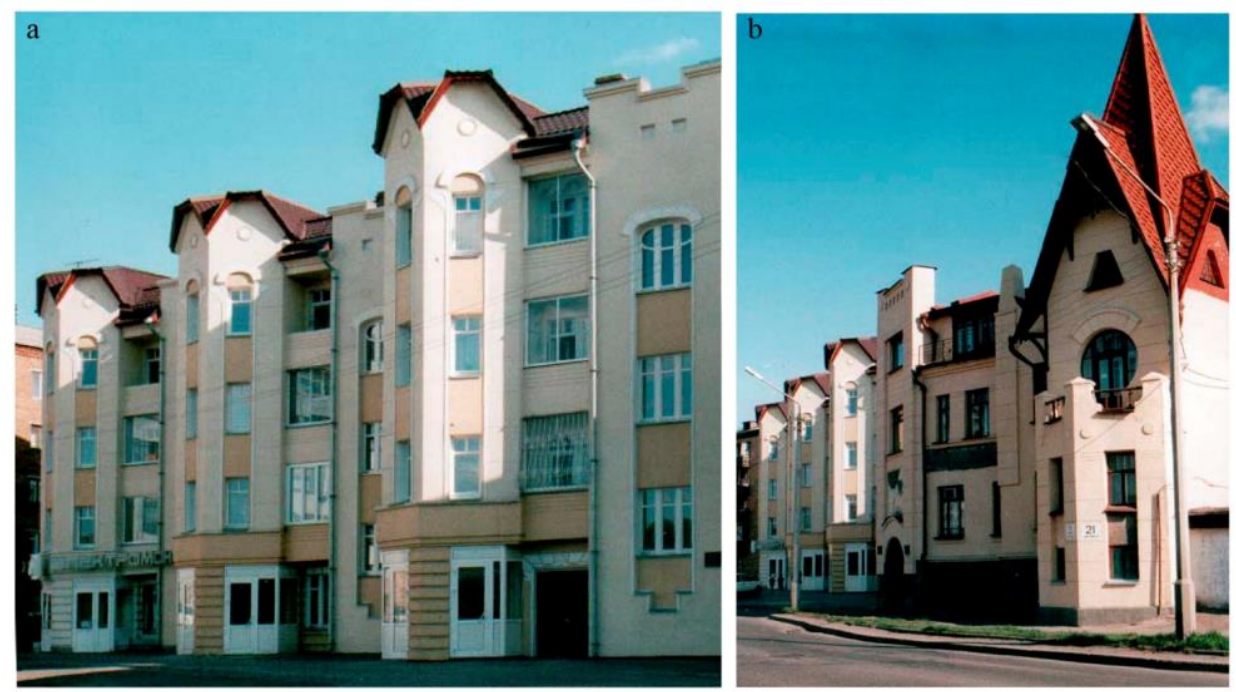

Figure 3 Residential building (19 Markovskogo Street): a - The residential building facade; $b$ - View of a residential building next to the architect Chernyshev's house, an architectural monument. 
Other residential buildings built in the 1990s and early 2000s in different districts of Krasnoyarsk, have traditional elements to diversify architectural design of buildings: triangular gables along the roof contour, cornices, bay windows, semicircular windows, arched lintels, imitation of rust, decorative details in the form of a consignment note. The color design of the facades was based on the sequence of red, gray, and yellow bricks and white details; and plastered gray surfaces and white details. Newly built brick buildings, rich win detail and color, began to add variety to the massive gray panel building of the Siberian city.

The greatest changes in the morphology of the living environment of Krasnoyarsk have taken place over the past 20 years. Housing construction based on the principles of investment and equity participation has become widely spread in all Russian cities. Over the past 20 years, almost 2,000 residential buildings have been built in Krasnoyarsk. Since the late 1990s, the real estate market has started to fill up with luxury buildings and luxury housing.

In the new housing stock, along with houses dotted in the historical part of the city, residential complexes of the newly developed territories dominate (undeveloped areas of the city, areas left after discontinued factories, dilapidated low-rise residential buildings, artificial embankments).

As part of the scientific work within the project supported by the Krasnoyarsk Regional Science Foundation, data on 480 residential complexes were collected and analyzed. In this study we employed the following methods: collection of statistical data, GIS (geographic information system) data study, GIS data collecting, field examination, photographic recording of residential buildings and complexes, search for information on the websites of design and construction organizations and residential complexes. While analysing architectural and art organization of residential buildings and complexes we employed the following parameters: number of storeys, shape, silhouette, plastic and facade details, facade decoration material, color design, functional and volumetric solution of the first floor, landscaping of the territory belonging to the residential complex. We identified the most typical and most remarkable in terms of architectural and art design residential complexes among those we examined. Representatives of these groups are collected in the analytical "Table 1".
Small subdistricts of the "Yuzhny Bereg" residential complex were designed following the European pattern by the SM.CITY construction company. In order to comply with the European principles for a living environment the Dutch company KCAP Architects\&Planners was invited. The company is known for its work on the master plan of the German HafenCity in Hamburg [13,14]. All the ideas embedded in the "Yuzhny Bereg" project were implemented in detail. "Yuzhny Bereg" includes 6-8-storey residential buildings with the private courtyard, which is closed to outsiders, the parking is located underground. There is the promenade from the outside along the entire territory. The first floors of the houses are occupied by shops, cafes, and offices. The walls are made of large ceramic blocks. High-quality finishes are applied both on the facades of the buildings and in landscaping of the complex. Small subdistricts of the "Yuzhny Bereg" project were recognized most comfortable living environment in Krasnoyarsk.

A large-scale construction of six-storey houses was also implemented in Preobrazhensky residential complex ("Table 1"). It was designed in cooperation with the Japanese architectural bureau Nikken Sekkei. The main idea of the project is creating comfortable urban environment with everything one may need for comfortable living. The initial idea "everything for people" is underlined by the smart city technologies. The facades of the buildings are made of various materials, they all contribute to creating an integral architectural design using compositional techniques: a clear contrasting demarcation of the residential block from the first commercial floors and roofs using color design. The complex includes various housing categories - comfort, prestige, premium.

The analytical table shows that in Krasnoyarsk most of the modern residential complexes under investigation have an increased number of storeys, line building or linear development, or their combinations.

The residential complex "Scandis" ("Table 1"), consisting of ten high-rise buildings, was built according to the principles of infill development. The integrated design unites the territory of the residential complex. Natural motives can be traced both in the principles of landscaping the territory and in the architecture of houses itself. Special attention is given to the elements of the facades of the lower floors; materials imitating natural stone were used in the facades. Each entrance group of 
the complex is made with designer finishes. Apartments on the second floors have "French" balconies with glazing from the floor level and decorative grilles on the outside. Most of the apartments have bay windows with the same glazing from the floor level starting from the 3rd floor. In general, the design of this residential complex corresponds to comfort class level of architectural environment.
Examples of uncomfortable residential complexes are "Beliye Rosy" and "Edelveis" ("Table 1"). The residential complex "Beliye Rosy" is located on the lower terrace of the right bank of the Yenisei, among the high-density line buildings of 24 and 25 storeys. Despite the frame monolithic construction system, the external design of buildings, the facades with identical glazed balconies resemble the monotonous architecture of panel houses.

Table 1. Analysis of modern residential complexes in the Krasnoyarsk

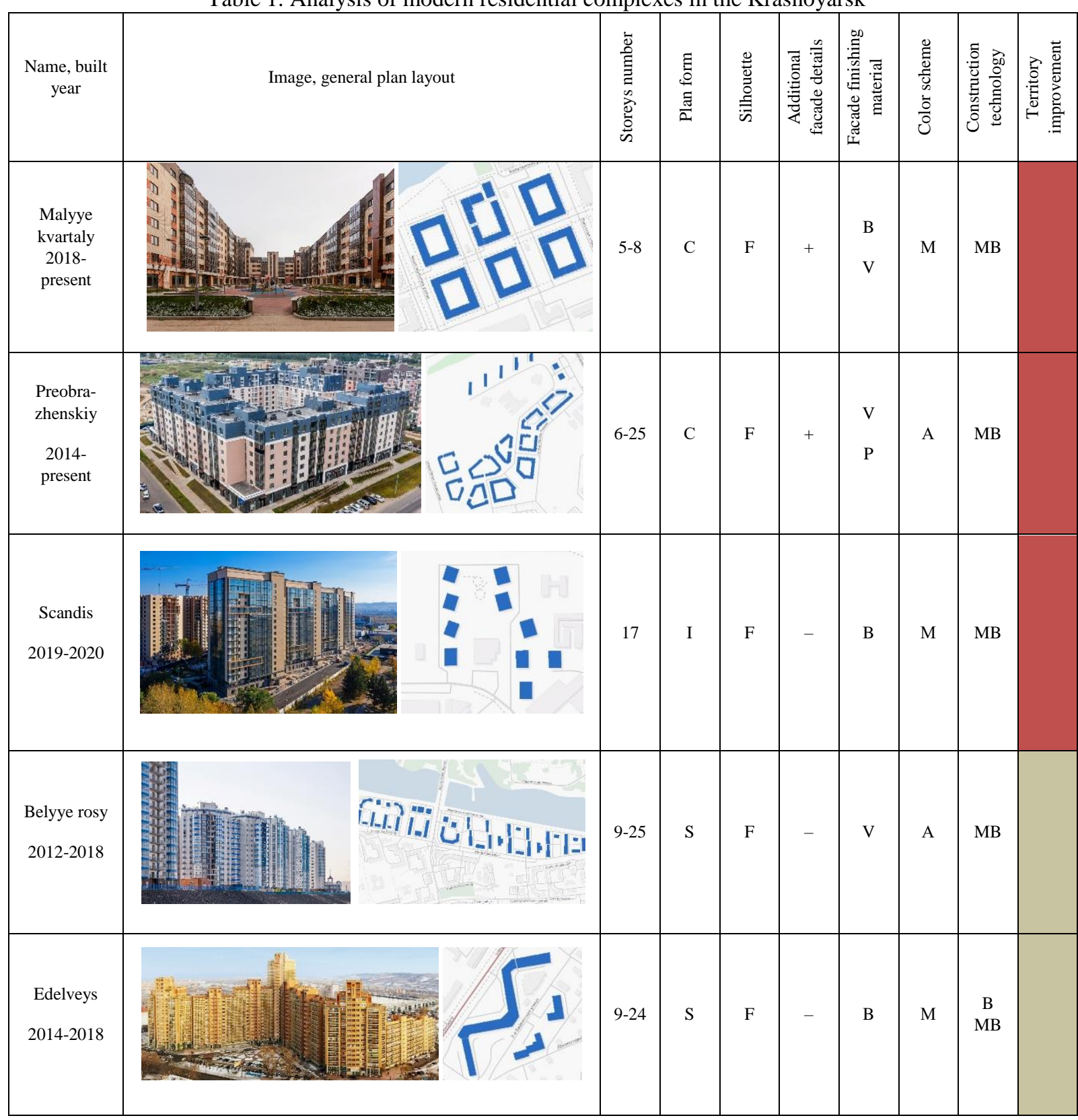




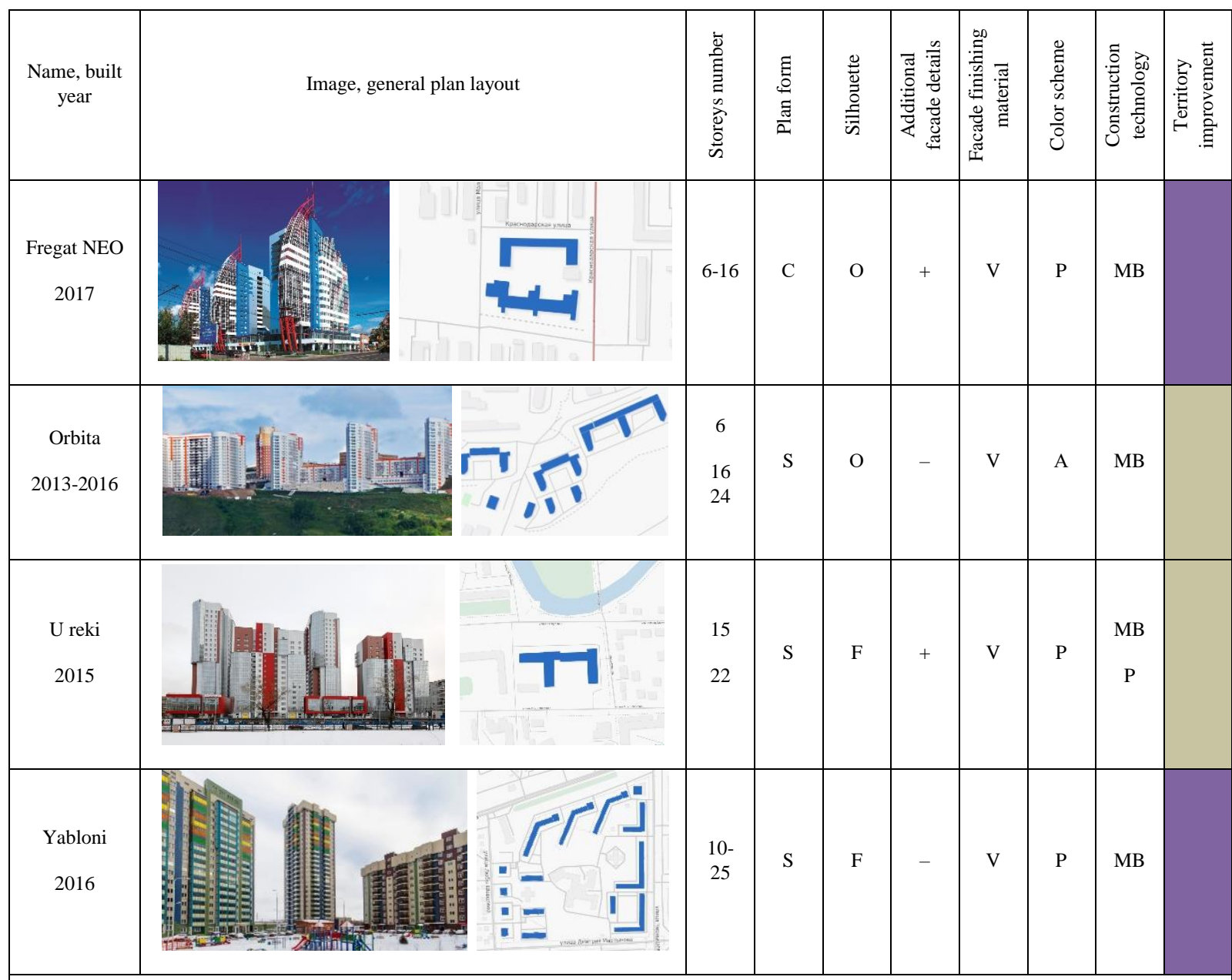

The «Table 1» uses the following legend: Plan form: HB - housing block, LB - line building, PB - point block; Silhouette: F - flat, O - original; Additional facade details: + presence, - absence; Facade finishing material: $\mathrm{B}$ - brick, $\mathrm{V}$ - ventilated systems, $\mathrm{P}$ - plaster; Facade color scheme: $\mathrm{M}$ monochrome (shades of 1 color), A - accent ( 2 colors), $\mathrm{P}$ - polychrome (more than 2 colors); Construction technology: B - brick, $\mathrm{P}$ - panel, MB monolithic-brick, monolithic-frame; Territory improvement: $\square-1$ (maximum), $\square-2$ (average), $\square-$

The residential complex "Edelveis" is an extended multi-section residential building consisting of sections having variable number of storeys. The planning composition of this house is a broken line in the form of a giant letter "M". The central 24-storey section of the house is solid cast and brick. All other sections are made of brick. The "brick" architecture sets the color design of the complex. Brick made it was possible to add protruding staircases and elevators to the upper contour of the house. The dehumanizing scale of a huge broken line of different height in a cramped surrounding space, and the lack of good landscaping of the territory significantly reduce the quality characteristics of the living environment of this complex.

The remarkable residential complex "Fregat NEO" ("Table 1") is designed in the form of a three-mast clipper ship. It is positioned as a closed complex with a comfortable level of living corresponding to the free $\&$ guard concept. The architectural design of the residential complex is based on the original silhouette of the three rhythmically designed high-rise volumes, constituting the two-tier public stylobate. The facades of the buildings are enriched with protrusions of vertical planes, with a combination of large glazed and blank surfaces. The color design reflects the marine theme. Shades of blue and light blue predominate in the color design, there are the 
horizontal, rhythmically arranged stripes, and the accent is laid on the "red masts of the ship". This is the example of an outstanding design, though one may argue about the large scale of this residential complex.

The "Orbita" residential complex in Studenchesky Gorodok is located on the high left bank of the Yenisei ("Table 1"). It is the example when the initial original architectural project was not implemented. The frame monolithic and brick complex is significantly inferior to the architectural design of the initial project. The construction within the following years of six additional 24-storey residential buildings of this complex turned it into a chaotic jumble of high volumes on a small steep slope. The active geomorphic landforms complicate landscaping, as a result it is still in poor condition and does not meet the needs of the residents.

All the residential complexes under investigation have a particular color design. One may easily identify monochrome, polychrome and color accents.

The residential complex "U Reki" (Table 1), the name of which originated from its location near the embankment of the Kacha River, is the example of a bright contrasting design of facades using active red color. The multicolor "Yabloni" residential complex ("Table 1"), the name of which reflects the preserved apple orchard, follows the image of a tree in its design: background brown-beige color is complemented by contrasting green, orange and yellow accents. The composition principles observed in the facades of the "Yabloni" residential complex are a darker color design of the lower floor which is intended for shops and offices, bright accent balconies, and massive elements of the technical floor.

The architectural design of a residential building or complex is inseparable from how the surrounding environment looks like, how well the landscaping is done and maintained, on the level of accessibility, condition of the small architectural forms, children's playgrounds, sports grounds, and recreation facilities. The architectural design of multi-family residential buildings, like any buildings, requires constant monitoring, and, if necessary, repair and reconstruction.

\section{CONCLUSION}

The analyzed materials make it possible to assert that multi-family residential buildings and complexes of Krasnoyarsk, according to their architectural design, can be attributed to the three groups: pre-industrial construction (first half of the 20th century), industrial construction (second half of the 20th century) and post-industrial construction (early 21 st century).

Multi-family residential buildings of the preindustrial construction period are represented by the isolated examples of Krasnoyarsk tenement houses of the early 20th century and residential buildings built from the late 1920 s to the mid-1950s. The design of the houses of this period demonstrates architectural characteristic features of Art Nouveau, Constructivism, Neoclassicism and the Stalinist Empire style. Construction of residential buildings within this period was not widely spread. Almost all the preserved houses of Krasnoyarsk of this period are architectural monuments and belong to the Heritage category.

Krasnoyarsk multi-family residential buildings of the industrial construction period of the second half of the 20th century, designed to solve the housing problem, were built according to the standard projects. The architectural design of these buildings is simple, ascetic and has low aesthetic characteristics. The main advantages of this housing are its economy, the opportunity to supply families with separate apartments, and optimal planning solutions. The construction of multifamily residential buildings based on industrial methods was of massive character, and traditional for this period. Now it may be regarded as a Soviet heritage. Nowadays, old architecture, Soviet heritage and new architecture should coexist, preserving the best traditions of industrial housing construction as the basis for developing and improving multi-family housing in subsequent times.

Multi-apartment residential buildings of the post-industrial construction period are numerous residential complexes built in Krasnoyarsk since the beginning of the $21 \mathrm{st}$ century. Their construction is based not only on the probated and improved traditional technologies of brick and panel housing construction, but also on modern hybrid frame monolithic and brick technologies. The projects include the latest technologies for both interior and exterior design. Architects strive to find bright individual solutions, which are sometimes controversial. There are cases when the resulting building does not correspond in full detail to the initial architectural design. In general, residential complexes are becoming diverse in content, layout, shape, composition, number of storeys, color 
design, materials used, facades and many other parameters. Taking into consideration the different financial capabilities of consumers, the housing is designed at different levels of comfort. The class of housing is demonstrated by its exterior design.

In the course of study, we defined the main problems of the architectural design shaping modern multi-family residential complexes in Krasnoyarsk. These are violation of the scale characteristics due to the predominance of high-rise buildings, and low quality of landscaping of most complexes.

We may conclude that nowadays Krasnoyarsk is undergoing the process of probation of various architectural designs of residential complexes, including identification of negative and positive aspects of certain solutions. Theoretical generalization and practical work carried out within this research will contribute to further improving of the architectural design of multi-family residential buildings and complexes.

\section{AUTHORS' CONTRIBUTIONS}

Olga Bliankinshtein - scientific supervision of the research, Abstract, Part I "Introduction", Part IV "Innovations shaping architectural formation of multi-family residential complexes in Krasnoyarsk at the beginning of the XXI century", Part V "Conclusion", editing.

Olesya Kiseleva - Part III "Architectural traditions shaping multi-apartment residential buildings in Krasnoyarsk in the second half of the 20th century"

Olga Uspenskaya - Part II "Architectural and art heritage shaping multi-family residential buildings in Krasnoyarsk in the first half of the 20th century".

Anastasiya Orlova - Part IV "Innovations shaping architectural formation of multi-family residential complexes in Krasnoyarsk at the beginning of the 21 st century", analytical table, layout.

Anastasiya Shlokina - Part IV "Innovations shaping architectural formation of multi-family residential complexes in Krasnoyarsk at the beginning of the 21 st century", analytical table, layout.

\section{REFERENCES}

[1] O.A. Zygmunt, The historical development of the housing policy of Russian cities from preindustrialization period to free real estate market, Planning Perspectives 07 (2019). DOI: $10.1080 / 02665433.2019 .1642236$.

[2] A.V. Kalabin, A.B. Kukovyakin, Mass residential development: problems and prospects (Massovaia zhilaia zastroika: problemy i perspektivy), Academic Bulletin UralNIIproekt RAASN (Akademicheskii Vestnik UralNIIproekt RAASN) 3 (34) (2017) 55-60 [in Russian].

[3] L.N. Danyaeva, K.V. Postnova, Architectural and typological formation of multi-storey residential buildings (Arkhitekturnotipologicheskoe formirovanie mnogoetazhnykh zhilykh zdanii), NNGASU, Nizhniy Novgorod, 2019 [in Russian].

[4] D.B. Litvintsev, Evolution of construction of apartment buildings in the mirror of sociology (Evoliutsiia stroitel'stva mnogokvartirnykh domov v zerkale sotsiologii), Urban studies 2 (2020) 88-99. DOI: 10.7256/23108673.2020.2.32976 [in Russian].

[5] E. V. Khitsenko, Architectural creativity of the city union of housing cooperatives of Novosibirsk during the first five-year plan (Arhitekturnoe tvorchestvo gorodskogo soiuza zhilishchnoi kooperacii Novosibirska v gody pervoi piatiletki). Tomsk state university journal. Culturology and art history (Vestnik Tomskogo Gosudarstvennogo universiteta) 40 (2020) 197-207. DOI: 10.17223 / 22220836/40/17 [in Russian].

[6] Y. I. Tarasova, Architectural-decorative design of profitable houses in cities of Western Siberia (Arhitekturno-dekorativnoe ubranstvo dohodnyh domov $\mathrm{v}$ gorodah Zapadnoi Sibiri), World of science, culture, education (Mir nauki, kultury, obrazovaniia) 5 (42) (2013) 351-352 [in Russian].

[7] E. Dorozhkina, A. Pastukhov, A. Averyanova, K. Stepanov, Eco-trends in the decoration of facades of houses of modern industrial series, E3S Web of Conferences 244 (2021), p. 05029.

DOI: https://doi.org/10.1051/e3sconf/20212440502 9 
[8] V.T. Gorbachev, N.N Kradin, N.P. Kradin, V.I. Krushlinskii, T M. Stepanskaya, V.I. Tsarev, Features of the development of Krasnoyarsk in the 19th and early 20th centuries (Osobennosti zastroiki Krasnoiarska v 19-nachala 20 veka), in: V.I. Tsarev (Eds.), Urban planning of Siberia (Gradostroitelstvo v Sibiri), Kolo Publishing House Ltd., SaintPetersburg, 2011, pp. 473-508 [in Russian].

[9] E.A. Bakhareva, V.G. Butorin, E.V. Ostasheva, V.A. Pirogov, A.A. Savchenko, Architectural and historical heritage of the city of Krasnoyarsk (Arkhitecturno-istoricheskoe nasledie goroda Krasnoiarska). Printing house Polikom, Krasnoyark, 2019, pp. 110-133 [in Russian].

[10] Resolution of the Central Committee of the CPSU and the Council of Ministers of the USSR No. 1871 of November 4, 1955 "On elimination of excesses in design and construction" (Postanovleniye TSK KPSS i Soveta ministrov SSSR №1871 ot 4 noyabrya 1955 g. «Ob ustranenii izlishestv v proyektirovanii i stroitel'stve») URL: https://strelkamag.com/ru/article/postanovleni e-ob-otkaze-ot-izlizhestv-full [in Russian]

[11] Resolution of the Central Committee of the CPSU and the Council of Ministers of the USSR No. 931 of July 31, 1957 "On housing construction development in the USSR" (Postanovleniye TSK KPSS i Soveta ministrov SSSR №931 ot 31 iyulya $1957 \mathrm{~g}$. «O razvitii zhilishchnogo stroitel'stva v $\mathrm{SSSR} \gg)$

URL: https://strelkamag.com/ru/article/postanovleni e-ob-otkaze-ot-izlizhestv-full [in Russian]

[12] S. Hirt, K. Stanilov, The perils of postsocialist transformation: Residential development in Sofia, in: Stanilov K. (Eds) The Post-Socialist City. The GeoJournal Library, vol. 92. Springer, 2007, pp. 215-244.

[13] A. Olshevich, HafenCity: sustainable development of the territory (HafenCity: ustoichivoe razvitie territorii) Project Baikal 27(2011) 78-85 [in Russian].

[14] G.N. Cherkasov, London, Hamburg. Unused opportunities of architecture (London, Gamburg. (Neispol'zovannye vozmozhnosti arkhitektury) Academia. Architecture and construction (Academiia. Arkhitektura i stroitel'stvo) 3 (2013) 27-40 [in Russian]. 